\title{
Determination of Adrenal Response After Oral Administration of Multiple Doses of Methylprednisolone
}

\author{
DYAl C. GARG, Ph.D."* JOHN G. WAGNER, Ph.D., JAMES W. AYRES, Ph.D.»* and \\ KENNETH S. ALBERT, Ph.D. Ann Arbor and Kalamazoo, Mich.
}

Normal cortisol production by the adrenals has a circadian rhythm, and many studies ${ }^{1-6}$ have shown a variation of plasma cortisol with the time of day. Migeon et al. ${ }^{7}$ showed that the diurnal variation of plasma levels of 17-hydroxycorticosteroids in night workers and blind persons was the same as that in normal subjects. Hellman et al. ${ }^{8}$ showed that cortisol was secreted intermittently rather than continuously.

Fluorescence, ${ }^{9}$ competitive protein binding, ${ }^{10}$ radioimmunoassay, ${ }^{11}$ and enzymelabeled immunoassay ${ }^{12}$ have all been used to measure plasma levels of cortisol. Highpressure liquid chromatographic (HPLC) analysis has obtained considerable attention recently for the determination of steroids in biologic fluids and pharmaceutical products. ${ }^{18-16}$ In our laboratory, an HPLC assay was developed for simultaneous determination of both hydrocortisone and methylprednisolone in plasma using

From the College of Pharmacy and Upjohn Center for Clinical Pharmacology, The University of Michigan, Ann Arbor, Mich., and The Upjohn Company, Kalamazoo, Mich. Supported by The Upjohn Company, Kalamazoo, Mich.

- Present address: Department of Pharmacology, Clinical Division, University of Miami, Miami, Fla. 33101.

- Present address: Bchool of Pharmacy, Oregon State University, Corvallis, Oregon 97331.

644 methylprednisolone acetate as internal standard. ${ }^{17}$

It has been documented in the literature that glucocorticoid therapy can be a cause of adrenal insufficiency. Plasma cortisol levels have been found to be low after glucocorticoid therapy. ${ }^{18,10}$ Using the response of the plasma 17-hydroxycorticosteroids to a 4-hour infusion of ACTH, Christy et al. ${ }^{20}$ demonstrated an impair. ment of response in six patients who were administered 20 to $30 \mathrm{mg}$ prednisone over a period of five to 13 days. This report describes the results of a study designed to ascertain the effect of multiple oral doses of methylprednisolone on adrenal function by measuring endogenous plasma levels of cortisol in each of 12 normal subjects during six days of therapy with methylprednisolone tablets and to evaluate adrenal response after corticotropin stimulation by measuring plasma levels of endogenous cortisol for 24 hours after intramuscular administration of synthetic ACTH both before and after methylprednisolone treatment.

\section{Materials and Methods}

Two treatments were administered to 12 normal male volunteers between the ages of 19 and 29 years with body weights from 64 to $99 \mathrm{~kg}$. All subjects underwent

The Journal of Clinical Pharmacology 
a comprehensive physical examination and provided a complete medical history before acceptance into the study. All possible side effects and risks involved were fully explained, and the subjects signed consent forms. The clinical study was carried out at Harris Laboratories, Lincoln, Nebraska. Subjects selected for the study did not receive any repository steroid preparation during the 60 days before the study or any other steroid preparation including topical steroids during the 14 days before the study. None of the subjects was a heavy user of alcohol. Subjects received no other medication for seven days before the study, and none was allowed throughout the duration of the study. Additionally, subjects did not drink alcoholic beverages and avoided strenuous exercise. Smoking was permitted if it was the usual habit. The study consisted of two treatments.

\section{Treatment A (Control)}

Blood samples were collected on days 1 to 3. Sample collection started at 8:00 P.M. on day 1 (zero time for this treatment) and ended at 8:00 P.M. on day 3. During the 48-hour period a total of 17 blood samples and two urine samples were collected per subject. Ten blood samples were collected in the interval 0-24 hours (8:00 P.M. of day 1 to 8:00 P.M. of day 2), and a 0-24 hour urine sample was collected. Synthetic ACTH, $0.25 \mathrm{mg}$, was administered into the upper, outer quadrant of the right buttock at 8:00 P.M. on day 2, i.e., 24 hours after the study started. Seven blood samples were collected in the interval 25-48 hours, and a 24-48 hour (8:00 P.M. on day 2 to 8:00 P.M. on day 3) urine sample was collected. Plasma was separated after centrifugation and stored at $-20^{\circ} \mathrm{C}$ until analyzed. Urine volume was measured, and an aliquot was stored in the freezer for analysis. There was a one-week interval between treatments $A$ and $B$ from day 3 to day 9.

\section{Treatment $B$}

Samples were collected on days 9 through 16, but 7:00 A.M. on day 9 was designated "zero time" for this treatment. Methylprednisolone administration (6- $\alpha$-methylprednisolone tablets, Medrol Dosepak") began at 7:00 A.M. ("zero time") on day 9 and continued according to the schedule given in Table I until the last tablet was given at 7:00 A.M. on day 14 (120 hours after zero time). The ACTH (Cortrosyn**) challenge was given at 157 hours (8:00 P.M. on day 15). During methylprednisolone administration (0-120 hours) a total of 43 blood samples were taken. From cessation of administration of tablets at 120 hours and the time of the ACTH injection, another 12 blood samples were taken (121-157 hours). Then, seven more blood samples were taken between 158 and 181 hours, and a 24-hour urine sample was taken after the ACTH injection in the interval 158-181 hours. Plasma was separated from the blood samples and frozen in vials, properly labeled, until analyzed. Urine volume was measured, and an aliquot was stored at $-20^{\circ} \mathrm{C}$ for analysis.

\section{Assay Method}

A high-pressure liquid chromatographic (HPLC) method was used for the simultaneous determination of both cortisol and methylprednisolone in plasma and urine. ${ }^{17}$ To check the day-to-day variation of the analytical procedure, two sets of quality control samples were prepared with the use of human plasma. These samples were spiked with only methylprednisolone because it was thought that the endogenous cortisol would be sufficient to give a reasonable response on the HPLC. One or two quality control samples were run each day the unknowns were run.

\footnotetext{
* Trademark of The Upjohn Company, Kalamazoo, Mich.

** Trademark of Organon, Ine., West Orange, N.J.
} 


\section{Results and Discussion}

\section{Precision of the HPLC Method}

The precision of the HPLC method was indicated by coefficients of variation calculated from two types of data. First, the average coefficient of variation calculated from concentrations estimated with the use of standard curve data was $6.62 \%$ (range 1.22 to $12.7 \%$ ) for cortisol and $7.33 \%$ (range 1.53 to $12.1 \%$ ) for methylprednisolone. Secondly, the coefficients of variation of the concentrations estimated from the analysis of the quality control samples were 4.2 and $6.0 \%$ (first set of quality control samples analyzed over 14 days) and 4.9 and $4.1 \%$ (second set of quality control samples analyzed over 15 days) for cortisol and methylprednisolone, respectively.

\section{Plasma Levels of Cortisol and Methylprednisolone}

Average plasma concentrations of cortisol after treatment $A$ are plotted in Fig. 1. Average plasma cortisol and methylprednisolone concentrations after treatment $B$ are plotted in Fig. 2. The first half of Fig. 1 gives the diurnal variation in cortisol levels over a 24-hour period. The 0-hour (8:00 P.M.) concentration averaged $40.5 \mathrm{ng} / \mathrm{ml}$ (range 18 to $67.9 \mathrm{ng} / \mathrm{ml}$ ). The 11-hour (7:00 A.M.) average plasma concentration was 117 $\mathrm{ng} / \mathrm{ml}$ (range 72.3 to $196 \mathrm{ng} / \mathrm{ml}$ ). The average plasma concentration of cortisol in the 24-hour sample (8:00 P.M. on the second day) was $55.5 \mathrm{ng} / \mathrm{ml}$ (range 32.7 to $124 \mathrm{ng} / \mathrm{ml}$ ).

Plots of individual subject concentrations of cortisol (not illustrated) showed peaks and troughs, as has been indicated by other authors. $1,3,8,21$ In this study the sampling was not as frequent as in some of the other studies, but with the sampling schedule we used we also saw episodes of secretory activity during the whole 24-hour interval. Average plasma levels of cortisol as plotted in Fig. 1 do not show as many peaks and troughs as were seen in individual subject plots.

Intramuscular injection of ACTH at 24 hours (8:00 P.M., second day) caused immediate stimulation of adrenocortical function as seen by an increase in plasma cortisol levels (Fig. 1). The average 9:00 P.M. cortisol concentration on day 1 was $36.2 \mathrm{ng} / \mathrm{ml}$ (range 13.7 to $76.6 \mathrm{ng} / \mathrm{ml}$ ), whereas the average 9:00 P.M. cortisol concentration on day 2 was $249 \mathrm{ng} / \mathrm{ml}$

TABLE I

Methylprednisolone Dosage*

\begin{tabular}{lcccccc}
\hline & & & \multicolumn{4}{c}{ Number of 4-mg tablets at** } \\
\cline { 4 - 7 } Day & $\begin{array}{c}\text { No. of } \\
\text { 4-mg } \\
\text { tablets }\end{array}$ & $\begin{array}{c}\text { Total daily } \\
\text { dose (mg) }\end{array}$ & $\begin{array}{c}\text { 7:00 A.M. } \\
\text { (Before } \\
\text { breakfast) }\end{array}$ & $\begin{array}{c}\text { 12:00 noon } \\
\text { (After } \\
\text { lunch) }\end{array}$ & $\begin{array}{c}\text { 6:00 P.M. } \\
\text { (After } \\
\text { supper) }\end{array}$ & $\begin{array}{c}\text { 11:00 P.M. } \\
\text { (Bedtime) }\end{array}$ \\
\hline 9 & 6 & 24 & 2 & 1 & 1 & 2 \\
10 & 5 & 20 & 1 & 1 & 1 & 2 \\
11 & 4 & 16 & 1 & 1 & 1 & 1 \\
12 & 3 & 12 & 1 & 1 & 0 & 1 \\
13 & 2 & 8 & 1 & 0 & 0 & 1 \\
14 & 1 & 4 & 1 & 0 & 0 & 0 \\
\hline
\end{tabular}

* Twenty-one 4-mg 6- $\alpha$-methylprednisolone tablets are supplied in each Medrol Dosepak.

*" Meals given: breakfast, 6:30 to 7:00 A.M.; lunch, 11:30 A.M. to 12:00 noon; dinner, 5:30

to 6:00 P.M.; snack, 10:30 to 11:00 P.M. 


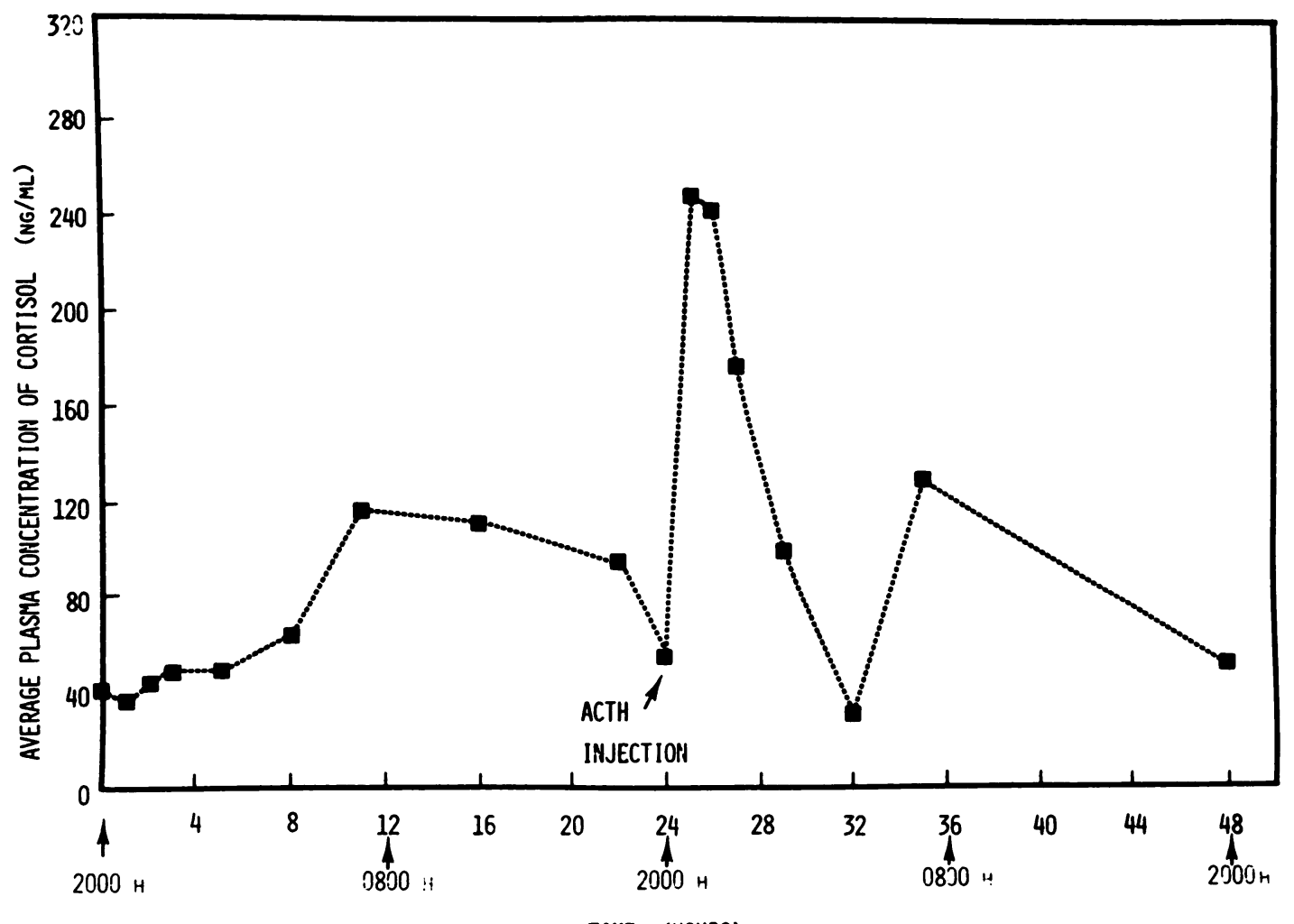

TIME (HOURS)

Fig. 1. Mean plasma concentration of cortisol after treatment A.

(range 177 to $324 \mathrm{ng} / \mathrm{ml}$ ). There have been other studies in which the effect of ACTH administration on changes in plasma levels or urinary levels of 17-hydroxycorticosteroids has been studied in both normal and diseased states. Eik-Nes et al. ${ }^{22}$ showed that plasma 17-hydroxycorticosteroids changed from $100 \mathrm{ng} / \mathrm{ml}$ to about $400 \mathrm{ng} / \mathrm{ml}$ after administration of 25 I.U. ACTH by infusion over 6 hours. In a similar study, Schmidt et al. 23 administered 40 I.U. ACTH by infusion over 6 hours (9:00 A.M. to 3:00 P.M.) and found that plasma levels changed from $185 \mathrm{ng} / \mathrm{ml}$ (8:00 A.M.) to $560 \mathrm{ng} / \mathrm{ml} \mathrm{(4:00}$ P.M.) on day 1 and from $160 \mathrm{ng} / \mathrm{ml}(8: 00$ A.M.) to $700 \mathrm{ng} / \mathrm{ml}$ (4:00 P.M.) on day 2 . Average plasma concentrations of cortisol and methylprednisolone after treatment $B$ are plotted in Fig. 2. It was found that after one day of therapy, endogenous cortisol declined to a limiting value of about $10 \mathrm{ng} / \mathrm{ml}$ and remained at about that level for five days. By the end of day 6 (about 10 hours after the last methylprednisolone tablet was given), the secretion of the adrenal gland tended toward normal as evidenced by the steady rise in serum levels of endogenous cortisol during the interval of 130-157 hours (normal recovery). Administration of ACTH (0.25 mg) at 157 hours, intramuscularly, caused a rapid increase in plasma cortisol concentrations.

\section{Adrenal Response to ACTH Stimulation Before Methylprednisolone Treatment}

Adrenalcortical response was evaluated in two ways: (a) by calculating areas under individual subject hydrocortisone 
concentration-time curves by means of the trapezoidal rule and obtaining the average area; and (b) by comparing cortisol concentrations 1 hour after ACTH administration.

Trapezoidal areas $\left(A U C_{0-24 \mathrm{hr}}\right.$ and $A U C_{24-48 \mathrm{br}}$ ) for cortisol were calculated following treatment $A$, and the areas $(\mathrm{ng} \cdot \mathrm{hr} / \mathrm{ml})$ are given in Table II.

The ratios and differences of $A U C_{24-48 \mathrm{hr}}$ and $A U C_{0-24 \mathrm{hr}}$ were calculated, and these values are included in Table II. For treatment A, response to ACTH was evaluated by considering the $A U C_{24-48 \text { br }}$ versus the $A U C_{0-24 \mathrm{br}}$ since ACTH was given at 24 hours. The mean $A U C_{24-48 \text { hr }}$ was $2532 \mathrm{ng} \cdot \mathrm{hr} / \mathrm{ml}$, while the mean $A U C_{0-24} \mathrm{hr}$ was $2015 \mathrm{ng} \cdot \mathrm{hr} / \mathrm{ml}$; the difference ${ }^{t}$ in mean areas was signifcant $(t=3.79,0.0025>P>0.0005)$.

The ratio $\ddagger$ of the two areas, $A U C_{24-48 \mathrm{mr}} /$ $A U C_{0-24} \mathrm{br}$, was significantly different

$\dagger$ For difference in areas,

$$
t=\frac{\bar{d}}{\sqrt{\frac{\Sigma d^{2}-(\Sigma d)^{2} / n}{n(n-1)}}}
$$

where $\bar{d}$ is the mean difference, $d$ is an individual difference from one pair, and $n$ is the number of pairs.

$\ddagger$ For the ratio of areas,

$$
t=\frac{|1-R|}{\text { 8.E. of } R}
$$

where $R=A D C_{24-48 \mathrm{hr}} / A D C_{0-24 \mathrm{hr}}$.

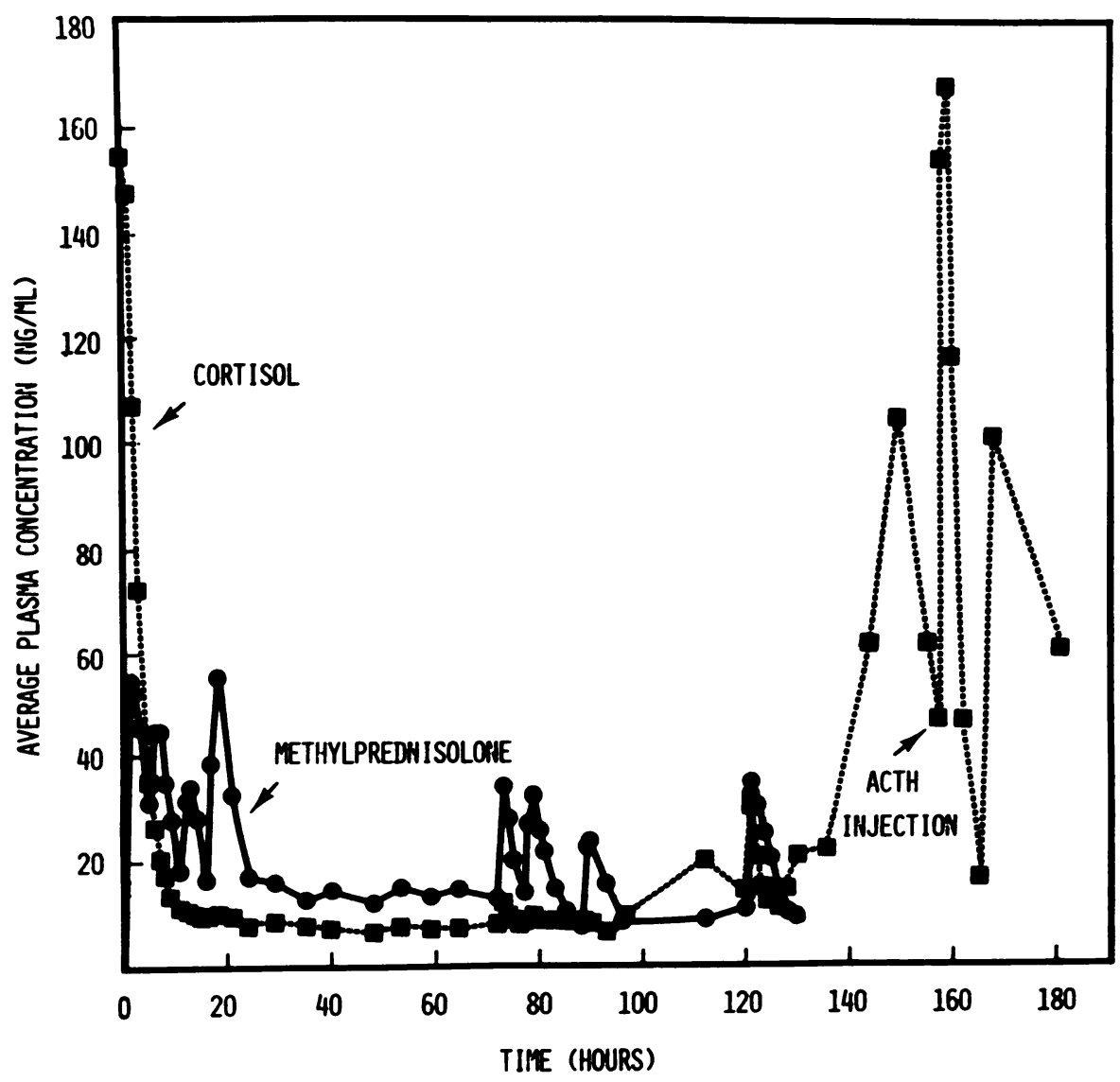

Fig. 2. Mean plasma concentrations of cortisol and methylprednisolone after treatment $B$. 
TABLE II

\begin{tabular}{|c|c|c|c|c|}
\hline \multirow{2}{*}{$\begin{array}{c}\text { Subject } \\
\text { no. }\end{array}$} & \multicolumn{2}{|c|}{$A U C(\mathrm{ng} \cdot \mathrm{hr} / \mathrm{ml})$} & \multirow{2}{*}{$\begin{array}{c}\text { Ratio } \\
\Delta U C_{21-48} \\
/ A U C_{0-24} \\
\end{array}$} & \multirow{2}{*}{$\begin{array}{c}\text { Difference } \\
A D C_{24-48}-\Delta U C_{0-24} \\
(\mathrm{ng} \cdot \mathrm{hr} / \mathrm{ml})\end{array}$} \\
\hline & $0-24 \mathrm{hr}$ & $24-48 \mathrm{hr}$ & & \\
\hline 1 & 1438 & 1740 & 1.21 & 302 \\
\hline 2 & 1660 & 2356 & 1.42 & 696 \\
\hline 3 & 1663 & 2972 & 1.79 & 1309 \\
\hline 4 & 1975 & 2352 & 1.19 & 377 \\
\hline 5 & 2935 & 3561 & 1.21 & 626 \\
\hline 6 & 1956 & 2181 & 1.12 & 225 \\
\hline 7 & 1703 & 2322 & 1.36 & 619 \\
\hline 8 & 2057 & 2927 & 1.42 & 870 \\
\hline 9 & 1916 & 2932 & 1.53 & 1016 \\
\hline 10 & 2436 & 2870 & 1.18 & 434 \\
\hline 11 & 2263 & 2566 & 1.13 & 303 \\
\hline 12 & 2179 & 1601 & 0.73 & -578 \\
\hline Mean & 2015 & 2532 & $1.27 *$ & $517^{* *}$ \\
\hline C.v. (\%) & 20.1 & 22.0 & 20.5 & 91.5 \\
\hline
\end{tabular}

- Ratio is significantly different from unity $(t=3.59,0.01>P>0.001)$.

* * Mean difference is significant (paired $t=3.79,0.0025>P>0.0005$ ).

from unity $(t=3.59,0.01>P>0.001)$. The effect of ACTH on adrenal function seemed to be instantaneous, and the effect deereased within 3 to 4 hours after administration.

\section{Adrenal Response to ACTH Stimulation After Methylprednisolone Treatment}

Trapezoidal areas $\left(A D C_{130-157 \text { br }}\right.$ and $A U C_{157-181 \mathrm{hr}}$ ) were ealculated for cortisol after treatment $B$, and these values are given in Table III. The recovery of the adrenal gland after methylprednisolone treatment was quite rapid. We designated the $A D C_{180-157} \mathrm{mr}$ as a measure of normal recovery of the adrenal gland after multiple-dowe treatments of methylprednisolone and the $A U C_{157-181 \text { br as a }}$ measure of ACTH response plus normal recovery. The mean $A U C_{167-181}$ or was $1947 \mathrm{ng} \cdot \mathrm{hr} / \mathrm{ml}$, while the mean $A D C_{130}$ $107 \mathrm{mr}$ was $1495 \mathrm{ng} \cdot \mathrm{hr} / \mathrm{ml}$; the difference

Oetober 1979 in means was significant $(t=5.59, P<$ $0.005)$. The mean ratio of $1.34, A U C_{157-}$ $181 \mathrm{br}) / A U C_{180-157 \mathrm{hr}}$, was significantly different from unity $(t=5.06, \quad P<$ 0.0005).

The average $A U C_{130-157 \mathrm{br}}$ of 1495 $\mathrm{ng} \cdot \mathrm{hr} / \mathrm{ml}(\mathrm{C.V} .=28.1 \%)$ for cortisol after treatment $B$ was about 74 per cent of the average $A U C_{0-24} \mathrm{hr}$ of $2015 \mathrm{ng} \cdot \mathrm{hr} /$ ml (C.V. $=20.1 \%$ ) after treatment $A$, indieating the fast recovery of the adrenal gland after methylprednisolone treatment was terminated.

Responsiveness of adrenal function to ACTH before and after methylprednisolone treatment was evaluated by comparing $A U C_{24-48 \mathrm{br}}$ for treatment $A$ and $A D C_{157-181 \mathrm{hr}}$ for treatment $B$. The average $A U C_{24-18 \mathrm{hr}}$ was $2532 \mathrm{ng} \cdot \mathrm{hr} / \mathrm{ml}$ (C.V. $=22.0 \%)$, while the average $\Delta U C_{157-181}$ or was $1947 \mathrm{ng} \cdot \mathrm{hr} / \mathrm{ml}$ (C.V. $=$ $25.1 \%$ ); the difference in means was sig- 
nificant $(t=4.71, P<0.001)$. The mean $A U C_{157-181 \mathrm{hr}}$ of $1947 \mathrm{ng} \cdot \mathrm{hr} / \mathrm{ml}$ was 77 per cent of the mean $A U C_{24-8 \mathrm{hr}}$ of 2532 $\mathrm{ng} \cdot \mathrm{hr} / \mathrm{ml}$, indicating a 23 per cent reduction in area attributable to multipledose administration of methylprednisolone.

Since ACTH was administered at 8:00 P.M. in both treatments, comparison of plasma cortisol concentrations in 9:00 P.M. samples was made as a measure of responsiveness to ACTH both before and after methylprednisolone treatment. The plasma cortisol levels are listed in Table IV. The paired $t$ for cortisol levels after ACTH (25 hours) and those before ACTH (1 hour) after treatment $A$ was $23.8(P<0.0005)$. The paired $t$ for cortisol levels in 158-hour samples after treatment $B$ and those in 25-hour samples after treatment $A$ was 9.56 ( $P<$ 0.0005 ). This was in agreement with the comparison of areas.

\section{Urinary Data}

The quality of the urinary data was not nearly as good as that of the plasma concentration data because of interfering peaks in the HPLC tracings from urine samples. The amounts of unconjugated cortisol $(\mu \mathrm{g})$ excreted in three intervals are presented in Table $V$. After treatment $A$, the mean amount of cortisol excreted in the 0-24 hour period was 39.4 $\mu \mathrm{g}$, while in the $24-48$ hour period the mean amount excreted was $86.6 \mu \mathrm{g}$; the difference in the means was significant $(t=4.72, P<0.005)$. The mean amount

TABIEE III

Areas Fstimated by Trapezoidal Rule from Observed Cortisol Plasma Concentrations for Treatment B

\begin{tabular}{|c|c|c|c|c|}
\hline \multirow[b]{2}{*}{$\begin{array}{c}\text { Subject } \\
\text { no. }\end{array}$} & \multicolumn{2}{|c|}{$A D C(\mathrm{ng} \cdot \mathrm{hr} / \mathrm{ml})$} & \multirow[b]{2}{*}{$\begin{array}{l}\text { Ratio } \\
A D C_{157-181} \\
/ A D C_{130-157}\end{array}$} & \multirow[b]{2}{*}{$\begin{array}{c}\text { Difference } \\
\Delta D C_{16 \mathrm{~g}-181}-\Delta U C_{180-167} \\
(\mathrm{ng} \cdot \mathrm{hr} / \mathrm{ml})\end{array}$} \\
\hline & $\begin{array}{l}130-157 \mathrm{hr} \\
\text { Normal } \\
\text { recovery }\end{array}$ & $\begin{array}{c}157-181 \mathrm{hr} \\
\text { ACTH response } \\
+ \text { normal recovery }\end{array}$ & & \\
\hline 1 & 817 & 1229 & 1.50 & 412 \\
\hline 2 & 1448 & 1958 & 1.35 & 510 \\
\hline 3 & 1573 & 1724 & 1.10 & 151 \\
\hline 4 & 2152 & 2212 & 1.03 & 61 \\
\hline 5 & 1729 & 2769 & 1.60 & 1040 \\
\hline 6 & 1287 & 1646 & 1.28 & 359 \\
\hline 7 & 790 & 1470 & 1.86 & 680 \\
\hline 8 & 1830 & 2644 & 1.44 & 813 \\
\hline 8 & 1635 & 2006 & 1.23 & 371 \\
\hline 10 & 1988 & 2428 & 1.22 & 440 \\
\hline 11 & 1240 & 1428 & 1.15 & 188 \\
\hline 12 & 1445 & 1854 & 1.88 & 409 \\
\hline Mean & 1495 & 1947 & $1.34^{*}$ & $453^{* *}$ \\
\hline C.V. (\%) & 28.1 & 25.1 & 17.4 & 61.8 \\
\hline
\end{tabular}

* Ratio is significantly different from unity ( $t=5.055, P<0.0005)$.

** Mean difference is significant (paired $t=5.59, P<0.005$ ). 
TABLE IV

Plasma Cortisol Concentrations (ng/ml) in 11:00 P.M. Samples Bofore and After ACTH Injection

\begin{tabular}{|c|c|c|c|}
\hline \multirow[b]{2}{*}{$\begin{array}{c}\text { Subject } \\
\text { no. }\end{array}$} & \multicolumn{2}{|c|}{ Treatment A } & \multirow{2}{*}{$\begin{array}{c}\text { Treatment B } \\
\text { After ACTH } \\
(158 \mathrm{hr})\end{array}$} \\
\hline & $\begin{array}{c}\text { Before ACTH } \\
(1 \mathrm{hr})\end{array}$ & $\begin{array}{l}\text { After ACTH } \\
(25 \mathrm{hr})\end{array}$ & \\
\hline 1 & 24.7 & 212 & 96.4 \\
\hline 2 & 34.7 & 215 & 157 \\
\hline 3 & 33.4 & 250 & 166 \\
\hline 4 & 45.2 & 291 & 195 \\
\hline 5 & 76.6 & 324 & 191 \\
\hline 6 & 29.5 & 177 & 151 \\
\hline 7 & 21.0 & 255 & 129 \\
\hline 8 & 46.5 & 239 & 174 \\
\hline 9 & 45.2 & 270 & 179 \\
\hline 10 & 38.6 & 262 & 146 \\
\hline 11 & 25.1 & 278 & 125 \\
\hline 12 & 13.7 & 222 & 133 \\
\hline Mean & $36.2^{*}$ & $249 * t$ & $154 \nmid$ \\
\hline C.V. (\%) & 45.2 & 15.7 & 19.1 \\
\hline
\end{tabular}

* Paired $t=23.8(P<0.0005)$.

t Paired $t=9.56(P<0.0005)$.

excreted in the 157-181 hour period after treatment $B$ was $61.0 \mu \mathrm{g}$; this mean differed significantly from the mean of 39.4 $\mu \mathrm{g}$ in the 0-24 hour period $(t=2.76$, $0.01>P>0.005$ ) and also from the mean of $86.6 \mu \mathrm{g}$ for the $24-48$ hour pe$\operatorname{riod}(t=2.90,0.01>P>0.005)$.

The renal clearances of cortisol estimated from the post-ACTH data for both treatment $A$ and $B$ agree well based on the mean data as shown below :

Treatment A :

$$
\text { renal clearance }=\frac{\begin{array}{c}
\text { amount excreted } \\
24-48 \mathrm{hr}(\mu \mathrm{g})
\end{array}}{\underset{A U C_{24-48 \mathrm{hr}}}{(\mathrm{ng} \cdot \mathrm{hr} / \mathrm{ml})}} \times
$$$$
\frac{1000}{60}=\frac{86.6}{2532} \times \frac{1000}{60}=0.57 \mathrm{ml} / \mathrm{min}
$$

Treatment B :

$$
\begin{aligned}
& \text { renal clearance }=\frac{\begin{array}{c}
\text { amount excreted } \\
157-181 \mathrm{hr}(\mu \mathrm{g})
\end{array}}{\begin{array}{c}
A U C_{167-181} \mathrm{hr} \\
(\mathrm{ng} \cdot \mathrm{hr} / \mathrm{ml})
\end{array}} \times \\
& \frac{1000}{60}=\frac{61.0}{1947} \times \frac{1000}{60}=0.52 \mathrm{ml} / \mathrm{min}
\end{aligned}
$$

\section{Methylprednisolone Pharmacokinetics}

The apparent elimination rate constants from fall-off curves of methylprednisolone plasma concentration with time after the first, second, third, fourth, 13th, 14th, 15th, and 18th doses for each subject were calculated. The overall mean apparent elimination rate constant was $0.213 \mathrm{hr}^{-1}$, which corresponds to a halflife of 3.25 hours. This value for the halflife is very close to the 3.13 hours re- 
ported by Jenkins and Schemmel. ${ }^{24}$ Stjernholm and Katz ${ }^{25}$ reported a value of $2.75 \pm 0.82$ hours. Slaunwhite and Sandberg ${ }^{26}$ reported the much shorter value of 1.3 hours after administration of ${ }^{14} \mathrm{C}-6$ - $\alpha$-methylprednisolone intravenously to humans.

Trends in the magnitudes of the average $\beta$ (apparent elimination rate constant) values with dose number were investigated. If there was enzyme induction, one would expect the $\beta$ value to increase with increase in the dose number. If there was no enzyme induction, one would expect $\beta$ not to be related to the dose number. There was no evidence of enzyme induction of metabolism of methylprednisolone since the mean apparent elimination rate constant of the $12 \mathrm{sub}$ jects was not significantly correlated with the dose number $(r=-0.246, P>0.25)$.

\section{TABIEE V}

Amounts of Cortisol ( $\mu \varepsilon)$ Frcreted in Urino

\begin{tabular}{|c|c|c|c|}
\hline \multirow{2}{*}{$\begin{array}{l}\text { Subject } \\
\text { no. }\end{array}$} & \multicolumn{2}{|c|}{ Treatment A } & \multirow{2}{*}{$\begin{array}{l}\text { Treatment B } \\
(157-181 \mathrm{hr})\end{array}$} \\
\hline & $0-24 \mathrm{hr}$ & $24-48 \mathrm{hr}$ & \\
\hline 1 & 19.8 & 28.1 & 21.8 \\
\hline 8 & 31.0 & 98.6 & 38.0 \\
\hline 3 & 31.0 & 60.2 & 49.8 \\
\hline 4 & 22.1 & 120.8 & 61.5 \\
\hline 5 & 32.4 & 38.9 & 33.6 \\
\hline 6 & 35.5 & 66.6 & 66.8 \\
\hline 7 & 45.3 & 93.3 & 48.4 \\
\hline 8 & 48.6 & 189.7 & 143 \\
\hline 9 & 25.9 & 96.9 & 64.0 \\
\hline 10 & 73.1 & 164 & 89.8 \\
\hline 11 & 46.5 & 84.5 & 50.8 \\
\hline 12 & 62.0 & 57.8 & 71.1 \\
\hline Mean & $39.4 * * *$ & $86.6^{*}+$ & $61.0 t^{* *}$ \\
\hline B.D. & 16.2 & 39.2 & 31.8 \\
\hline C.V. (\%) & 41.1 & 45.3 & 58.3 \\
\hline
\end{tabular}

- Paired $t=4.723$ ( $P<0.0005)$.

+ Paired $t=2.902(0.005<P<0.001)$.

*" Paired $t=8.759$ (0.005 $<P<0.01)$.

658

\section{Summary}

The effect of multiple oral doses of methylprednisolone on adrenal function was ascertained by measuring endogenous plasma levels of cortisol in each of 12 normal subjects during six days of progressively diminishing therapy with methylprednisolone tablets (4 mg each). Adrenal response was also evaluated after corticotropin stimulation by measuring plasma levels of endogenous cortisol for 24 hours after intramuscular administration of synthetic ACTH both before and after the start of the methylprednisolone treatment. It was found that after one day of methylprednisolone therapy, endogenous cortisol declined to a limiting value of about $10 \mathrm{ng} / \mathrm{ml}$ and remained at about that level for five days. About 10 hours after the last methylprednisolone tablet was given, the secretion of the adrenal gland tended toward normal as evidenced by the steady rise in plasma levels of endogenous cortisol during day 7. This conclusion is supported by results of the ACTH challenge, which showed that the area under the cortisol concentration-time curve through 24 hours was reduced by only 23 per cent after termination of methylprednisolone therapy. There was no evidence that methylprednisolone induced its own metabolism since the mean apparent elimination rate constant was not significantly correlated with dose. The overall average elimination rate constant was $0.213 \mathrm{hr}^{-1}$, corresponding to a half-life of 3.25 hours.

\section{References}

1. Krieger, D. T., Allen, W., Rizzo, F., and Krieger, H. P.: Characterisation of the normal temporal pattern of plasma corticosteroid levels. J. Clin. Endoorinol. Metab. 32:266 (1971).

2. deLacerda, L., Kowarski, A., and Migeon, C. J.: Integrated concentration and diurnal variation of plasma cortisol. $J$. Clin. Endocrimol. Metab. 86:887 (1973).

3. Gutai, J. P., Meyer III, W. J., Kowarald, A. A., and Migeon, C. J.: Twenty-four

The Journal of Clinical Pharmacology 


\section{ADRENAL RESPONSE TO METHYLPREDNISOLONE}

hour integrated concentrations of progesterone, 17-hydroxyprogesterone and cortisol in normal male subjects. J. Clin. Endoorinol. Metab. 44:116 (1977).

4. Perkoff, G. T., Eik-Nes, K., Nugent, C. A., Fred, H. L., Nimer, R. A., Rush, L., Samuels, L. T., and Tyler, P. H.: Studie on the diurnal variation of plasma 17-hydroxycorticosteroids in man. J. Clin. Endoorinol. $19: 432$ (1959).

5. Krieger, D. T., Glick, S., Silverberg, S., and Krieger, H. P.: A comparative study of endocrine tests in hypothalamic disease. Circadian periodicity of plasma 11-OHCS and growth hormone response to insulin hypoglycemia and metyrapone responsiveness. J. Clin. Endoorinol. 28:1589 (1968).

6. Yates, F. E., and Urquhart, J.: Control of plasma concentrations of adrenocortical hormones. Physiol. Rev. 42:359 (1962).

7. Migeon, C. J., Tyler, F. H., Mahoney, J. P., Florentin, A. A., Castle, H., Bliss, E. L., and Samuels, L. T.: The diurnal variation of plasma levels and urinary excretion of 17-hydroxycorticosteroids in normal subjects, night workers and blind subjects. J. Clin. Endocrinol. 16:622 (1956).

8. Hellman, L., Nakada, F., Curti, J., Weitzman, E. D., Kream, J., Roffwarg, H., Ellman, S., Fukushima, D. K., and Gallagher, T. F.: Cortisol is secreted episodically by normal man. J. Clin. Endocrinol. 30:411 (1970).

9. Dörner, G., and Stahl, F.: A simple fluorometric method for the routine assessment of adrenal cortical function. Ger. Med. Monthly 10:443 (1965).

10. Murphy, B. E. P., and Pattee, C. J.: Determination of plasma corticoids by compotitive protein binding analysis using gel filtration. J. Clin. Endocrinol. 24:919 (1964).

11. Farmer, R. W., and Pierce, C. E.: Plasma cortisol determination: radioimmunoassay and competitive protein binding compared. Clin. Chem. 20:411 (1974).

12. Ogihara, T., Miyai, K., Nishi, K., Ishibashi, K., and Kumahara, Y.: Enzyme-labelled immunoassay for plasma cortisol. J. Clin. Endocrinol. Metab. 44:91 (1977).

13. Loo, J. C. K., and Jordan, N.: High-performance liquid chromatographic analysis for synthetic corticosteroids in plasma. $J$. Chromatogr. 143 :314 (1977).

14. Trefz, F. K., Byrd, D. J., and Kochen, W.: Quantitative determination of cortisol in human plasma by high-pressure liquid chromatography. J. Chromatogr. 107:181 (1975).

15. Krzeminski, L. F., Cox, B. L., Perrel, P. N., and Schiltz, R. A.: Determination of methylprednisolone (Medrol) residues in milk by high-pressure liquid chromatography. Agric. Food Chom. 20:970 (1972).

16. Olson, M. C.: Analysis of adrenocortical steroids in pharmaceutical preparations by high-pressure liquid-liquid chromatography. J. Pharm. Soi. 62:2001 (1973).

17. Garg, D. C., Ayres, J. W., and Wagner, J. G.: Determination of methylprednisolone and hydrocortisone in plasma using high-preserure liquid chromatography. Bos. Commun. Chem. Pathol. Pharmacol. 18: 137 (1977).

18. Sampson, P. A., Brooke, B. N., and Winstone, N. E.: Biochemical confirmation of collapse due to adrenal failure. Lanoet $1: 1377$ (1961).

19. Sampson, P. A., Winstone, N. E., and Brooke, B. N.: Adrenal function in surgical patients after steroid therapy. Lancet $2: 322$ (1962).

20. Christy, N. P., Wallace, E. Z., and Jailer, J. W.: Comparative effects of prednisone and of cortisone in suppressing the response of the adrenal cortex to exogenous adrenocorticotropin, J. Clin. Endoorinol. Metab. 16:1059 (1956).

21. Weitzman, E. D., Fukushima, D. K., Nogeire, C., Roffwarg, H., Gallagher, T. F., and Hellman, L.: Twenty-four hour pattern of the episodic secretion of cortisol in normal subjects. J. Clin. Endoorinol. Metab. 33:14 (1971).

22. Eik-Nes, K., Sandberg, A. A., Migeon, C. J., Tyler, F. H., and Bamuels, L. T.: Changes in plasma levels of 17-hydroxycorticosteroids during the intravenous administration of ACTH. II. Response under various clinical conditions. J. Clin. En docrinol. $15: 13$ (1955).

23. Schmidt, K. J., Zysk, J., and Chu, T. M.: Competitive protein binding radioassay of plasma and urinary unconjugated cortisol. J. Med. 6:389 (1975).

24. Jenkins, D., and Schemmel, J. E.: Metabolic effects of 6-methylprednisolone. Metabolism 7:416 (1958).

25. Stjernholm, M. R., and Katz, F. H.: Effects of diphenylhydantoin, phenobarbital, and diazepam on the metabolism of methylprednisolone and its sodium succinate. $J$. Clin. Endoorinol. Metab. 41:887 (1975).

26. Slaunwhite, W. R., and Sandberg, A. A.: Disposition of radioactive 17-a-hydroxyprogesterone, 6- $\alpha$-methyl-17- $\alpha$-acetoxyprogesterone and 6-a-methylprednisolone in human subjects. J. Clin. Endoorinol. Metab. $21: 753$ (1961).

Reprint requests to: Kenneth 8. Albert, Ph.D., Medical Bioavailability Unit, The Upjohn Company, Kalamazoo, Mich. 49001. 